\title{
WINTER HOME RANGE OF THE MANCHURIAN WAPITI (CERVUS CANADENSIS XANTHOPYGUS) BASED ON NONINVASIVE SAMPLING
}

\author{
TIAN, X. M. ${ }^{1,2}-$ WANG, X. L. ${ }^{1}-$ ZHANG, M. H. ${ }^{1 *}$ \\ ${ }^{1}$ College of Wildlife and Protected Area, Northeast Forestry University, Harbin 150040, China \\ ${ }^{2}$ College of Life Science and Technology, Mudanjiang Normal University, Mudanjiang 157011, \\ China \\ *Corresponding author \\ e-mail: zhangminghai2004@126.com; phone: +86-139-3639-6197
}

(Received $5^{\text {th }}$ Aug 2019; accepted $15^{\text {th }}$ Nov 2019)

\begin{abstract}
The noninvasive sampling was applied to analyze the winter home range of the Manchurian wapiti (Cervus canadensis xanthopygus) in the east of the Wanda Mountains, north-eastern China's Heilongjiang Province. A total of 210 feces samples of the animal were collected from the study area during two consecutive winters. The DNAs were successfully extracted from 167 samples, and all genotypes of 7 microsatellite loci were obtained. Individual identification shows that the 167 samples belonged to 66 individuals. Through gender identification by the SRY gene, it was learned that the 66 individuals were 22 females and 44 males. Then, the winter home ranges of seven individuals ( 5 males and 2 females) were determined by Minimum Convex Polygons estimation. The results show that the winter home ranges of male individuals varied from 169.26 to $1,085.61 \mathrm{hm}^{2}$ (mean: $557.62 \pm 411.83 \mathrm{hm}^{2}$ ), while those of female individuals were $43.72 \mathrm{hm}^{2}$ and $14.71 \mathrm{hm}^{2}$ (mean: $\left.29.21 \pm 20.51 \mathrm{hm}^{2}\right)$. Finally, it is concluded that the noninvasive sampling is a feasible way to study the home range of endangered animals. This technique can be applied in the future to acquire more comprehensive information about the home range of animals.

Keywords: home range, noninvasive sampling, gender identification, minimum convex polygon method, animal movement, spatial distribution, Cervus canadensis xanthopygus
\end{abstract}

\section{Introduction}

The home range is the area in which animals perform daily activities such as feeding, mating, and breeding, and guarantees the normal survival and reproduction of animals (Burt, 1943). Home range research is very important for us to understand ungulate society organizations, improve the quality of their habitats, determine the optimal carrying capacity of their habitats, protect and reintroduce endangered species, and other projects (Howell, 1954; Dunbar and Dunbar, 1974; Inglis et al., 1979; Green, 1986; Cederlund and Okarma, 1988; Arcese, 1999; Woolnough and Toit, 2001). For large ungulates, traditional home range research methods are mainly radio telemetry and GPS collar tracking, the premise of which is to capture the wild animals, the capture process may cause injury to the individuals, and the collars worn by the animals may produce certain effects on their behaviors (Ensing et al., 2014; Kropil et al., 2015). The noninvasive sampling method can extract the DNA from the feces, hairs and urine left by the animals without disturbing them, and then through molecular marker individual identification and gender identification, and analysis of repeated sampling positions, the home range information could be obtained (Taberlet et al., 1997; Kohn et al., 1999; Smith et al., 2006). The combination of noninvasive sampling and GIS analysis overcomes the interference of traditional research methods on animals, and it receives 
wide attention from endangered wild animal researches as an auxiliary method for home range research.

The number of Manchurian wapiti (Cervus canadensis xanthopygus Milne-Edwards, 1867) within Chinese territory has continued to decline due to illegal hunting and habitat loss (Ohtaishi and Sheng, 1993). At the beginning of the 19th century, the Manchurian wapitis in Shanxi and Hebei provinces were extinct (Jiang et al., 2007). The current distribution of Manchurian wapiti is mainly limited to some parts of Northeast China (Heilongjiang, Inner Mongolia, and Jilin Provinces), Ningxia, Xinjiang, Gansu, Qinghai, Sichuan, and Tibet (Xu et al., 2000), and it has been listed as a secondary national protected wild animal (Wang, 1998).

The body size of the Manchurian wapitis distributed in northeastern China is big. The body weight of male individuals is $200-250 \mathrm{~kg}$ and that of female ones is about $150 \mathrm{~kg}$ (Fig. 1). Female individuals are mature sexually at 2 years old and usually give birth to one cub each time (Chen et al., 1997). The Manchurian wapitis are the main prey for the extremely endangered species Amur tiger (Panthera tigris altaica) and Amur leopard (Panthera pardus orientalis) (Li et al., 2001; Qi et al., 2015). In recent years, there has been a significant decline and retreat in the population and distribution of Manchurian wapitis in Northeast China (Xu et al., 2000). The Wanda Mountains area in northeastern China was once the largest population density distribution area of Manchurian wapiti in Heilongjiang Province (Chen et al., 1997). Habitat fragmentation and illegal hunting have led to a sharp decline in the number of Manchurian wapitis in the region (Zhang and Zhang, 2011; Zhou et al., 2015). The survey found that the population density of Manchurian wapiti in Wanda Mountains area was 1.05 individuals per $\mathrm{km}^{2}$ in 1989 , and 0.20 individuals per $\mathrm{km}^{2}$ in 2002 , with a annual decline rate of 13.48\% between 1989 and 2002 (Zhang and Zhang, 2011); while between 2004 and 2010 , the annual average decline rate of relative population abundance was $37.30 \%$ (Zhou et al., 2015); and the survey in 2015 showed that the Manchurian wapitis in Wanda Mountains were on the verge of extinction (Zhou, 2019, personal communication).

Therefore, this study analyzes the home range size of Manchurian wapiti in east Wanda Mountains area based on noninvasive sampling method, in the hopes of providing references for formulating restoration and protection strategies for Manchurian wapitis, and meanwhile discussing the feasibility of applying noninvasive sampling to the study of home range of endangered animals.

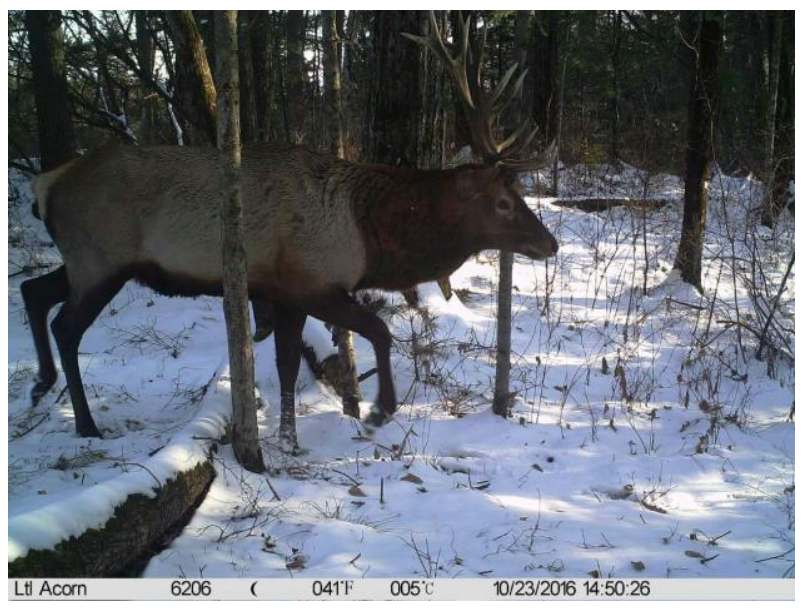

Figure 1. A male Manchurian wapiti monitored by an infrared camera in the study area 


\section{Materials and methods}

\section{Research area overview}

The research area is located in the Wupao Forest Farm of Yingchun Forestry Bureau in the eastern part of Wanda Mountains in Heilongjiang Province. The geographical coordinates are $46^{\circ} 27^{\prime}-46^{\circ} 38^{\prime} \mathrm{N}, 133^{\circ} 04^{\prime}-133^{\circ} 16^{\prime} \mathrm{E}$, and the total area of the forest farm is $155.6 \mathrm{~km}^{2}$ (Fig. 2). The area is in the cold temperate zone, and the weather condition is continental monsoon climate, with long winter and a frost-free period of about 120 days. The freezing period is relatively long and generally freezes in October and unfreezes in late April. The annual average temperature is $2.5-3.0{ }^{\circ} \mathrm{C}$, the annual rainfall is $500-600 \mathrm{~mm}$, and $60-70 \%$ rainfall is concentrated between June and August. The terrain of the area is low hills with an altitude of 300-500 m, and the forest area accounts for more than $80 \%$ of the total area. The large mammals distributed in this area include Siberian tiger (Panthera tigris altaica), Manchurian wapiti (Cervus elaphus xanthopygus), lynx (Lynx lynx), black bear (Ursus thibetanus), wild boar (Sus scrofa), roe deer (Capreolus capreolus), and sable (Martes zibellina), etc.

\section{Sample collection and DNA extraction}

During the winter of 2006 and 2007, samples were collected in the whole area of Wupao forest farm. Along the fresh footprint chains on the snow, feces of Manchurian wapiti were found, several feces were taken and put into the sealed bags, and the positions of the samples were located with GPS. Then other fresh footprint chains were followed and samples were collected as well. A total of 210 samples (120 in 2006 and 90 in 2007) were collected and stored and frozen at $-20{ }^{\circ} \mathrm{C}$ (Fig. 2). Four pieces of muscle samples of culled Manchurian wapitis were obtained from the Harbin Changcheng Deer Farm (Heilongjiang, China). DNA extraction of the feces was performed using the QIAamp DNA Stool Mini Kit (Qiagen, Germany) according to the manual; and muscle DNAs were extracted by phenol/chloroform; all extracted DNAs were stored at $-20^{\circ} \mathrm{C}$.

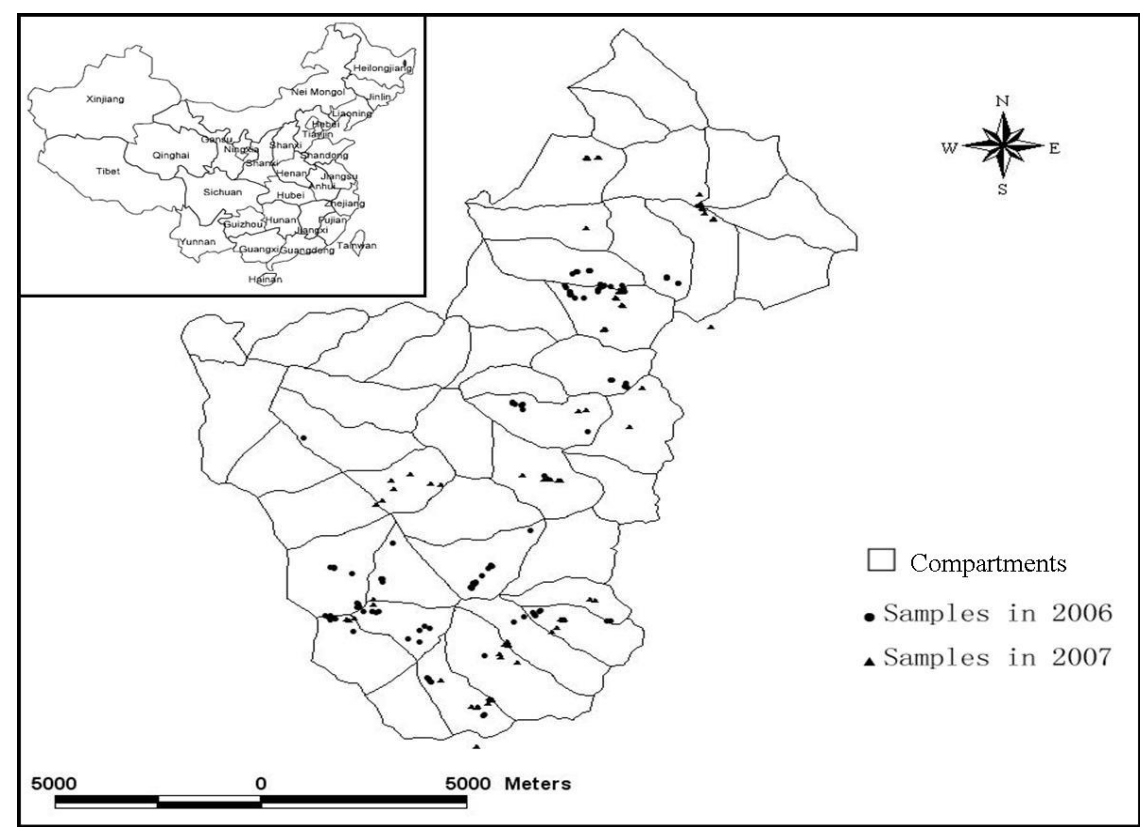

Figure 2. Sampling locations in the study area 


\section{Individual identification}

Seven microsatellite loci (T507, CSSM19, T530, T501, C143, T123, T156) with high polymorphism were selected, and the $5^{\prime}$ ends of the upstream primers of all microsatellite loci were fluorescently labeled (FAM, HEX, TAMARA). Primer information, PCR amplification and genotype identification procedures are described in the literature (Tian et al., 2010). Genotyping was performed using multi-tube PCR amplification method (Bellemain et al., 2005), for each locus, positive amplification was performed for 3-4 times to determine the final genotype (Tian and Zhang, 2010). Then the software Excel Mircosatellite Tool kit (Park, 2001) was adopted to find matching genotypes in the data. For different samples, if the genotype of all loci was the same or there's difference in only one allele in one locus, then the samples were judged to be from the same individual (Bellemain et al., 2005; Tian and Zhang, 2010). And then software Cervus 3.0 (Kalinowski et al., 2007) was used to calculate the joint $P_{\text {ID }}$ value and $P_{\text {sib value of the } 7 \text { loci. }}$

\section{Gender identification}

SRY12 and BMC1009 2 were used to carry out gender identification on the prime multiplex amplification, SRY12 was used to amplify the SRY12 segment of the Y chromosome, and BMC1009 2 was used as a positive control to amplify the autosomal microsatellite loci (Huber et al., 2002). Each sample had bee amplified for 3 times, if double bands appeared at least 2 times, then the sample was judged to be a female; if single band (300 bp BMC1009) appeared at least 2 times, then it is judged to be a male; for other situations, the PCR was performed again for the identification. The prime information and PCR amplification conditions are available in the literature (Tian and Zhang, 2010).

\section{Home range analysis}

According to the individual identification results, individuals that had been sampled 4 times, or more than 4 times had been selected, and home range analysis was performed according to each GPS position of the same individual. And the size of the home range was calculated by the Minimum Convex Polygons (MCP) using the ArcView 3.3a's amplification module Home Range Analysis (ESRI Inc.).

\section{Results}

In the 210 samples of extracted fecal DNA, some of the DNAs were yellow, no amplification product could be obtained, and these samples were subject to the secondtime DNA extraction. At last, 90 samples from 2006 and 77 samples from 2007 were used, and a total of 167 DNA samples were subject to subsequent analysis.

In the individual recognition, the combined discrimination rate of the 7 microsatellite loci was very high $\left(\mathrm{P}_{\mathrm{ID}}=1.3 \times 10^{-7}\right.$ and $\left.\mathrm{P}_{\mathrm{sib}}=0.19 \%\right)$, which means that for unrelated individuals, the probability of having the same genotype is $1.3 \times 10^{-7}$. Even in the case of twins, the probability of misjudgment is only $0.19 \%$. Individual identification results: there are 39 individuals in the 90 samples of 2006, 36 individuals in the 77 samples of 2007, the 167 samples of the two years belonged to 66 individuals. Out of the individuals of 2006, 9 individuals appeared repeatedly in 2007. 
To verify the accuracy of gender identification, 4 muscle samples ( 2 Male, 2 Female) and 4 fecal samples (2 Male, 2 Female) of known gender Manchurian wapitis in Harbin Changcheng Deer Farm (Heilongjiang, China) were analyzed. At the same time, 8 fecal samples (6 Male, 2 Female) whose gender was determined by the urinary positions of wild Manchurian wapitis' lying trace had been analyzed as well, and correct results were obtained (Fig. 3). Gender identification results: there are 28 male and 11 female individuals in the 39 individuals of 2006; there are 21 male and 15 female individuals in the 36 individuals of 2007; in the 66 individuals of the two years, there are 44 male and 22 female individuals.

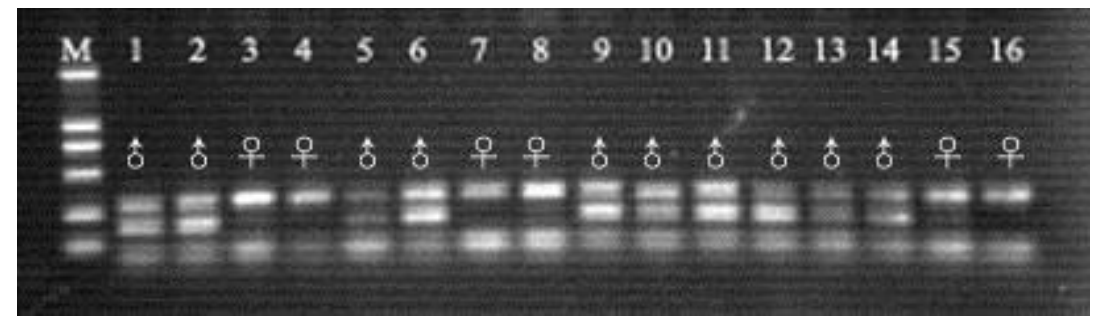

Figure 3. Amplification results of SRY12 and BMC1009 loci of samples with known gender; M: Marker DL-2000; 1-16: samples with known gender

In different years, there are fewer individuals that appeared repeatedly, so the home range analysis was performed for different years. Among the 66 individuals, 10 individuals with $\geq 4$ repeated samples were selected. As for the No. 1, No. 4 and No. 8 individuals, since the sampling time interval is too short, the range of activity is smaller, so these 3 individuals' home range values were removed as abnormal values. Finally, the winter home range size of 7 individuals was analyzed. The number of repeated samples of the 7 individuals was 4-9 times, with an average of 6.43 times (see Table 1). Based on MCP, the size of home range was calculated, the home range size area of male individuals was 169.26-1085.61 ha with an average of 557.62 \pm 411.83 ha; the home range areas of the 2 female individuals were 43.72 ha and 14.71 ha, with an average of $29.21 \pm 20.51$ ha. Compared with male individuals, female Manchurian wapiti's home range area is smaller (see Table 1; Fig. 4). There is a certain overlap in the range of activity between male individuals and between female and male individuals (see Fig. 4). Manchurian wapitis are gregarious animals. Since we cannot determine whether these 7 individuals are from the same group, the overlap of the Manchurian wapitis' home ranges had not been analyzed further.

\section{Discussion}

The size of the home range is the result of animal individual movement and spatial distribution of the population. Various factors such as age, gender, population density, season, food richness, predation risk, landscape spatial heterogeneity and human disturbance can affect the size of home range (Anderson et al., 2005; Reinecke et al., 2014; Kropil et al., 2015). According to the noninvasive sampling analysis, this study determined that the average size of winter home range of male wapiti individuals was 557.62 ha, this number for female individuals was 29.21 ha, and the male/female HRS ratio was 19.09. Compared with female wapitis, the male wapitis are larger in body size 
(Clutton-Brook et al., 1982; Chen et al., 1997), so they need to enlarge the home range to meet their physiological needs (Jetz et al., 2004), therefore, the home range size of most male wapitis is larger than that of the female ones (see Table 2). The study of Kamler et al. (2008) on wapiti home range shows that the male/female HRS ratios vary from 1.58 to 4.29, and the home ranges of female individuals (IDs 9 and 10, 43.72 ha and $14.71 \mathrm{ha}$ ) and male individuals (IDs 2 and 5, 169.26 ha and 205.23 ha) are quite small (see Table 1), and these results are closer to the winter home range of wapitis in related researches of Germany (female: $14 \pm 2.4$ ha, male: $12 \pm 2.5$ ha), Denmark (12February: $33.8 \pm 23.4$ ha, March: $53.3 \pm 19.2$ ha) and Poland (female: $106 \pm 12$ ha, male: $112 \pm 17 \mathrm{ha}$ ) (Georgii, 1980; Georgii and Schröder, 1983; Jeppesen, 1987; Kamler et al., 2007). The home range sizes of male individuals (IDs 3, 6 and 7) were 438.13 ha, 1085.61 ha and 889.85 ha, respectively, which is closer to the winter home size of wapitis in Europe and North America (see Table 2). We believe that the home ranges of female and male individuals (IDs 2 and 5) were smaller, the male/female HRS ratio is too high, insufficient sampling had resulted in deviations in these results, and the home range size of these individuals can only represent the range of activity of wapitis on a certain day or a few certain days in winter.

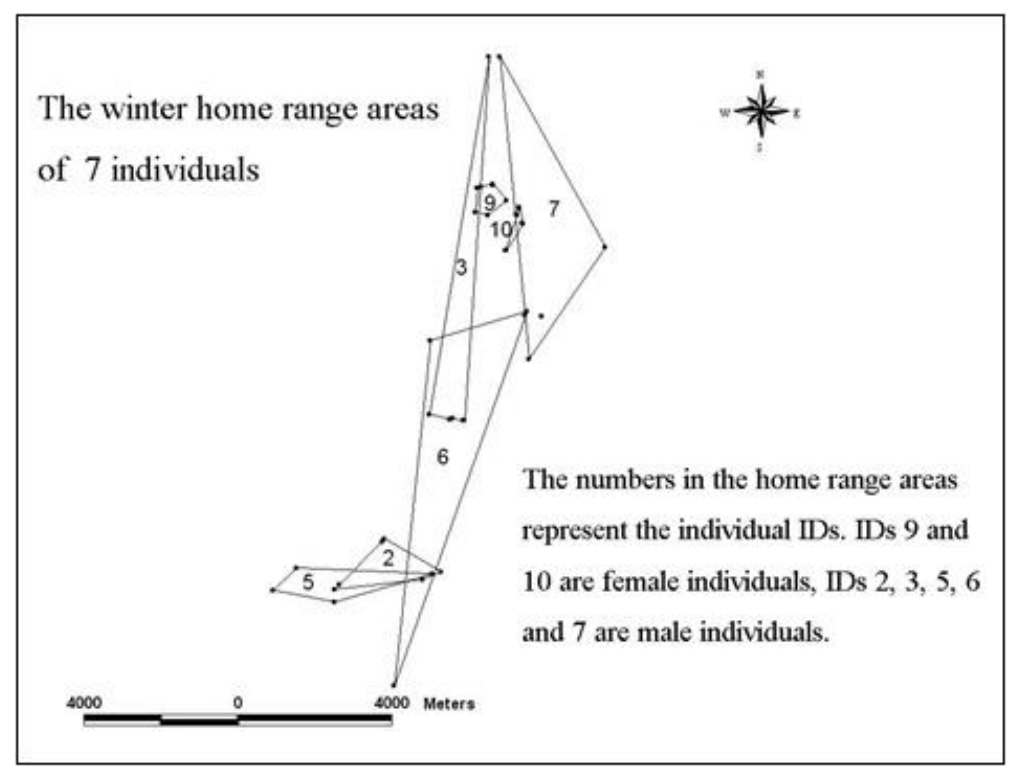

Figure 4. Winter home range sizes of wapitis calculated by $M C P$

Table 1. Analysis of winter home range sizes of wapitis

\begin{tabular}{c|c|c|c|c|c}
\hline $\begin{array}{c}\text { Individual } \\
\text { ID }\end{array}$ & Gender & $\begin{array}{c}\text { Repeated sampling } \\
\text { number }\end{array}$ & GPS coordinates & $\begin{array}{c}\text { Year of } \\
\text { sampling }\end{array}$ & $\begin{array}{c}\text { Home range size } \\
\text { (ha) }\end{array}$ \\
\hline & & & $46^{\circ} 29^{\prime} 40.4138^{\prime \prime} \mathrm{N}$, & & \\
& & & $133^{\circ} 10^{\prime} 50.1412^{\prime \prime} \mathrm{E}$ & & \\
& & & $46^{\circ} 9^{\prime} 33.5416^{\prime \prime} \mathrm{N}$, & & \\
2 & \multirow{3}{*}{ Male } & 5 & $133^{\circ} 10^{\prime} 27.2930^{\prime \prime} \mathrm{E}$ & & \\
& & & $46^{\circ} 30^{\prime} 04.7822^{\prime \prime} \mathrm{N}$, & 2006 & 169.26 \\
& & $133^{\circ} 09^{\prime} 38.1336^{\prime \prime} \mathrm{E}$ & & \\
& & & $46^{\circ} 30^{\prime} 07.2392^{\prime \prime} \mathrm{N}$, & & \\
& & $133^{\circ} 09^{\prime} 39.8799^{\prime \prime} \mathrm{E}$ & & \\
& & & $46^{\circ} 29^{\prime} 23.8251^{\prime \prime} \mathrm{N}$, & & \\
\hline
\end{tabular}




\begin{tabular}{|c|c|c|c|c|c|}
\hline 3 & Male & 8 & $\begin{array}{l}46^{\circ} 36^{\prime} 56.1911^{\prime \prime} \mathrm{N}, \\
133^{\circ} 11^{\prime} 34.5398^{\prime \prime} \mathrm{E} \\
46^{\circ} 31^{\prime} 49.4170^{\prime \prime} \mathrm{N}, \\
133^{\circ} 10^{\prime} 56.8140^{\prime \prime} \mathrm{E} \\
46^{\circ} 31^{\prime} 49.2191^{\prime \prime} \mathrm{N}, \\
133^{\circ} 10^{\prime} 56.5859^{\prime \prime} \mathrm{E} \\
46^{\circ} 31^{\prime} 49.2185^{\prime \prime} \mathrm{N}, \\
133^{\circ} 11^{\prime} 12.8690^{\prime \prime} \mathrm{E} \\
46^{\circ} 31^{\prime} 49.2166^{\prime \prime} \mathrm{N}, \\
133^{\circ} 11^{\prime} 14.7930^{\prime \prime} \mathrm{E} \\
46^{\circ} 31^{\prime} 49.0715^{\prime \prime} \mathrm{N}, \\
133^{\circ} 11^{\prime} 13.8124^{\prime \prime} \mathrm{E} \\
46^{\circ} 31^{\prime} 52.7444^{\prime \prime} \mathrm{N}, \\
133^{\circ} 10^{\prime} 31.8791^{\prime \prime} \mathrm{E} \\
46^{\circ} 31^{\prime} 50.2182^{\prime \prime} \mathrm{N}, \\
133^{\circ} 11^{\prime} 00.3536^{\prime \prime} \mathrm{E}\end{array}$ & 2007 & 438.13 \\
\hline 5 & Male & 5 & $\begin{array}{l}46^{\circ} 29^{\prime} 27.8412^{\prime \prime} \mathrm{N}, \\
133^{\circ} 08^{\prime} 46.7205^{\prime \prime} \mathrm{E} \\
46^{\circ} 29^{\prime} 38.7495^{\prime \prime} \mathrm{N}, \\
133^{\circ} 10^{\prime} 39.1767^{\prime \prime} \mathrm{E} \\
46^{\circ} 29^{\prime} 40.7186^{\prime \prime} \mathrm{N}, \\
133^{\circ} 07^{\prime} 54.2299^{\prime \prime} \mathrm{E} \\
46^{\circ} 29^{\prime} 21.4747^{\prime \prime} \mathrm{N}, \\
133^{\circ} 07^{\prime} 26.1455^{\prime \prime} \mathrm{E} \\
46^{\circ} 29^{\prime} 12.7009^{\prime \prime} \mathrm{N}, \\
133^{\circ} 08^{\prime} 41.7491^{\prime \prime} \mathrm{E}\end{array}$ & 2006 & 205.23 \\
\hline 6 & Male & 4 & $\begin{array}{l}46^{\circ} 33^{\prime} 22.1126^{\prime \prime} \mathrm{N}, \\
133^{\circ} 12^{\prime} 27.5197^{\prime \prime} \mathrm{E} \\
46^{\circ} 32^{\prime} 55.1068^{\prime \prime} \mathrm{N} \\
133^{\circ} 10^{\prime} 31.0565^{\prime \prime} \mathrm{E} \\
46^{\circ} 28^{\prime} 03.6527^{\prime \prime} \mathrm{N} \\
133^{\circ} 09^{\prime} 55.9965^{\prime \prime} \mathrm{E} \\
46^{\circ} 33^{\prime} 18.7175^{\prime \prime} \mathrm{N}, \\
133^{\circ} 12^{\prime} 25.8006^{\prime \prime} \mathrm{E}\end{array}$ & 2006 & 1085.61 \\
\hline 7 & Male & 6 & $\begin{array}{l}46^{\circ} 33^{\prime} 17.9203^{\prime \prime} \mathrm{N}, \\
133^{\circ} 12^{\prime} 45.2157^{\prime \prime} \mathrm{E} \\
46^{\circ} 34^{\prime} 43.7355^{\prime \prime} \mathrm{N}, \\
133^{\circ} 12^{\prime} 11.6790^{\prime \prime} \mathrm{E} \\
46^{\circ} 36^{\prime} 56.0080^{\prime \prime} \mathrm{N} \\
133^{\circ} 11^{\prime} 47.5645^{\prime \prime} \mathrm{E} \\
46^{\circ} 32^{\prime} 41.4994^{\prime \prime} \mathrm{N} \\
133^{\circ} 12^{\prime} 31.5793^{\prime \prime} \mathrm{E} \\
46^{\circ} 33^{\prime} 24.7041^{\prime \prime} \mathrm{N} \\
133^{\circ} 12^{\prime} 11.0494^{\prime \prime} \mathrm{E} \\
46^{\circ} 34^{\prime} 17.3325^{\prime \prime} \mathrm{N}, \\
133^{\circ} 14^{\prime} 01.3121^{\prime \prime} \mathrm{E}\end{array}$ & 2007 & 889.85 \\
\hline 9 & Female & 8 & $\begin{array}{l}46^{\circ} 34^{\prime} 54.7801^{\prime \prime} \mathrm{N}, \\
133^{\circ} 11^{\prime} 59.3837^{\prime \prime} \mathrm{E} \\
46^{\circ} 35^{\prime} 06.4236^{\prime \prime} \mathrm{N}, \\
133^{\circ} 11^{\prime} 27.6206^{\prime \prime} \mathrm{E} \\
46^{\circ} 35^{\prime} 08.5082^{\prime \prime} \mathrm{N}, \\
133^{\circ} 11^{\prime} 42.7235^{\prime \prime} \mathrm{E} \\
46^{\circ} 35^{\prime} 08.1101^{\prime \prime} \mathrm{N}, \\
133^{\circ} 11^{\prime} 42.1260^{\prime \prime} \mathrm{E} \\
46^{\circ} 34^{\prime} 42.0893^{\prime \prime} \mathrm{N}, \\
133^{\circ} 11^{\prime} 37.0720^{\prime \prime} \mathrm{E} \\
46^{\circ} 35^{\prime} 04.8008^{\prime \prime} \mathrm{N}, \\
133^{\circ} 11^{\prime} 23.3062^{\prime \prime} \mathrm{E} \\
46^{\circ} 35^{\prime} 07.7722^{\prime \prime} \mathrm{N}, \\
133^{\circ} 11^{\prime} 42.1859^{\prime \prime} \mathrm{E} \\
46^{\circ} 34^{\prime} 44.7024^{\prime \prime} \mathrm{N}, \\
133^{\circ} 11^{\prime} 22.0966^{\prime \prime} \mathrm{E}\end{array}$ & 2006 & 43.72 \\
\hline
\end{tabular}




\begin{tabular}{|c|c|c|c|c|c|}
\hline 10 & Female & 9 & $\begin{array}{l}46^{\circ} 34^{\prime} 42.6564^{\prime \prime} \mathrm{N}, \\
133^{\circ} 12^{\prime} 13.0767^{\prime \prime} \mathrm{E} \\
46^{\circ} 34^{\prime} 49.2009^{\prime \prime} \mathrm{N}, \\
133^{\circ} 12^{\prime} 15.3028^{\prime \prime} \mathrm{E} \\
46^{\circ} 34^{\prime} 48.8132^{\prime \prime} \mathrm{N}, \\
133^{\circ} 12^{\prime} 15.3626^{\prime \prime} \mathrm{E} \\
46^{\circ} 34^{\prime} 36.2776^{\prime \prime} \mathrm{N}, \\
133^{\circ} 12^{\prime} 19.3459^{\prime \prime} \mathrm{E} \\
46^{\circ} 34^{\prime} 35.4839^{\prime \prime} \mathrm{N}, \\
133^{\circ} 12^{\prime} 20.3584^{\prime \prime} \mathrm{E} \\
46^{\circ} 34^{\prime} 49.2009^{\prime \prime} \mathrm{N}, \\
133^{\circ} 12^{\prime} 15.3028^{\prime \prime} \mathrm{E} \\
46^{\circ} 34^{\prime} 12.8702^{\prime \prime} \mathrm{N}, \\
133^{\circ} 11^{\prime} 59.2212^{\prime \prime} \mathrm{E} \\
46^{\circ} 34^{\prime} 13.0977^{\prime \prime} \mathrm{N}, \\
133^{\circ} 12^{\prime} 01.3269^{\prime \prime} \mathrm{E} \\
46^{\circ} 34^{\prime} 48.6146^{\prime \prime} \mathrm{N}, \\
133^{\circ} 12^{\prime} 15.0873^{\prime \prime} \mathrm{E}\end{array}$ & 2007 & 14.71 \\
\hline
\end{tabular}

Table 2. Summary of winter home range of wapitis calculated by minimum convex polygon method

\begin{tabular}{|c|c|c|c|c|c|}
\hline Country & Region & $\begin{array}{c}\text { No. of } \\
\text { animals }\end{array}$ & HRS $\left(\mathbf{k m}^{2}\right)$ & Comments & Author \\
\hline Germany & Bavarian Alps & $10 q$ & $0.65 q$ & & Georgii, 1980 \\
\hline Germany & Bavarian Alps & $9{ }^{\lambda}$ & $1.13{ }^{\lambda}$ & & $\begin{array}{c}\text { Georgii and } \\
\text { Schröder, } 1983\end{array}$ \\
\hline Germany & $\begin{array}{c}\text { Grafenwöhr; } \\
\text { Kellerwald-Edersee } \\
\text { NP; } \\
\text { Schleswig-Holstein } \\
\end{array}$ & $37(\widehat{o}+q)$ & $\begin{array}{l}10-33 \hat{\jmath} \\
2.8-119\end{array}$ & & $\begin{array}{l}\text { Reinecke et al., } \\
2014\end{array}$ \\
\hline $\begin{array}{c}\text { Czech } \\
\text { Republic }\end{array}$ & Jeseniky Mts. & $3 \hat{\jmath}+5 q$ & $\begin{array}{l}0.84 \lesssim \\
0.35 \text { 우 } \\
\end{array}$ & $\begin{array}{l}\text { Monthly } \\
\text { ranges }\end{array}$ & $\begin{array}{c}\text { Koubek and Hrabe, } \\
1996 \\
\end{array}$ \\
\hline Slovakis & Kremnica Mts. & $20{ }^{\lambda}$ & $6.01: 8.26 \widehat{ठ}$ & $\begin{array}{l}\text { Resident: } \\
\text { Migrant }\end{array}$ & Kropil et al., 2015 \\
\hline America & Idaho & $4 \hat{\jmath}+12$ ㅇ & 2.1 average & & $\begin{array}{c}\text { Irwin and Peek, } \\
1983\end{array}$ \\
\hline $\begin{array}{l}\text { America; } \\
\text { Canada }\end{array}$ & $\begin{array}{l}\text { Wisconsin; } \\
\text { Yellowstone; } \\
\text { Alberta }\end{array}$ & $44+$ & $14.15-439.73 q$ & $95 \%$ kernel & $\begin{array}{l}\text { Anderson et al., } \\
2005\end{array}$ \\
\hline China & Heilongjiang & $5 \hat{\jmath}+2 \propto$ & $\begin{array}{c}1.69-10.86{ }^{\lambda} 0.15- \\
0.449\end{array}$ & & $\begin{array}{c}\text { Tian et al. (this } \\
\text { study) }\end{array}$ \\
\hline
\end{tabular}

Mts: mountains; NP: national park; HRS: home range size

This study suggests that it is feasible to study the home range of animals using noninvasive sampling method. Although traditional home research methods are still the mainstream methods of animal home range research, the noninvasive sampling method does not require animals to be captured, so it could obtain a large amount of genetic information without causing any interference to animals. Especially for rare and endangered wild animals with high alertness and complex distribution terrain, the noninvasive sampling method is more feasible for home range research of these animal species (Taberlet et al., 1997; Kohn et al., 1999; Smith et al., 2006). The analysis results 
suggest that using noninvasive sampling method to study animal home range requires larger sampling intensity, and it should be combined with the footprints, lying traces, feeding marks, and other location information to obtain more distribution points of a same individual so as to obtain the accurate size of home range. At the same time, the multi-tube approach should be performed strictly so as to eliminate allele dropouts and false alleles during fecal DNA microsatellite genotyping, and avoid false individual identification (Taberlet et al., 1996; Bellemain et al., 2005; Pérez-Espona et al., 2008). Moreover, by applying noninvasive sampling method for future studies we could obtain more comprehensive information of animal home range, such as individual daily home range, winter home range size, home range overlapping, core area, sub-herd home range, kinship, and diffusion, etc. At the same time, combining with factors such as population density, food richness, snow density, predation risk and human disturbance, the influencing factors of home range changes could be revealed.

\section{Conclusion}

Based on noninvasive sampling, the winter home ranges of male individuals of the Manchurian wapiti varied from 169.26 to $1,085.61 \mathrm{hm}^{2}$ (mean: $557.62 \pm 411.83 \mathrm{hm}^{2}$ ), while those of female individuals were $43.72 \mathrm{hm}^{2}$ and $14.71 \mathrm{hm}^{2}$ (mean: $29.21 \pm 20.51 \mathrm{hm}^{2}$ ). The winter home ranges of both females and several males were too small, due to the limited sample size.

Our analysis revealed that the noninvasive sampling is a feasible way to study the home range of endangered animals. It requires larger sampling intensity to obtain more accurate size of home range. The footprints, lying traces, feeding marks, and other location information should be considered to obtain more distribution points of the same individual. This study suggests that the noninvasive sampling method and traditional home range research method should be combined to reveal individual daily home range, winter home range size, home range overlapping, core area, sub-herd home range, kinship, diffusion and the influencing factors of home range changes. It proposes speeding up the construction of the reserve in Wanda Mountains to reduce the disturbance of human activities on the survival of the Manchurian wapiti.

Acknowledgements. Our study was funded by the Heilongjiang Provincial Basic Research Business Support Project, China (1353ZD006); National Science Foundation of China (30870309); Mudanjiang Normal College National Cultivation Project (Study on Population Spatial Genetic Structure and Dispersal Model of Manchurian Wapiti in Northeast China) and Excellent Youth Key Teacher Training Plan Project of Mudanjiang Normal College (MQP201405). We thank Y. Li and L. F. Wang for help given throughout this project. We appreciate help from the staff of Heilongjiang Provincial Forest Department, especially H. Y. Dong. We acknowledge the professional staff, guides, and drivers of Heilongjiang Provincial Yingchun Forest Bureau.

\section{REFERENCES}

[1] Anderson, D. P., Forester, J. D., Turner, M. G., Frair, J. L., Merrill, E. H., Fortin, D., Mao, J. S., Boyce, M. S. (2005): Factors influencing female home range sizes in elk (Cervus elaphus) in North American landscapes. - Landscape Ecology 20(3): 257-271.

[2] Arcese, P. (1999): Effect of auxiliary males on territory ownership in the Oribi and the attributes of multimale groups. - Animal Behaviour 57(1): 61-71. 
[3] Bellemain, E., Swenson, J. E., Tallmon, D., Brunberg, S., Taberlet, P. (2005): Estimating population size of elusive animals with DNA from hunter-collected feces: four methods for brown bears. - Conservation Biology 19(1): 150-161.

[4] Burt, W. H. (1943): Territoriality and home range concepts as applied to mammals. Journal of Mammalogy 24(3): 346-352.

[5] Cederlund, G., Okarma, H. (1988): Home range and habitat use of adult female moose Journal of Wildlife Management 52(2): 336-343.

[6] Chen, H. P., Wu, J. P., Zhang, M. H. (1997): Heilongjiang Provincial Red Deer. Northeast Forestry University Press, Harbin.

[7] Clutton-Brock, T. H., Guinness, F. E., Albon, S. D. (1982): Red Deer: Behavior and Ecology of Two Sexes. - Edinburgh University Press, Edinburgh.

[8] Dunbar, R. I. M., Dunbar, E. P. (1974): Social organization and ecology of the Klipspringer (Oreotragus oreotragus) in Ethiopia. - Ethology 35(5): 481-493.

[9] Ensing, E. P., Ciuti, S., de Wijs, F. A., Lentferink, D. H., Ten Hoedt, A., Boyce, M. S., Hut, R. A. (2014): GPS based daily activity patterns in European red deer and North American elk (Cervus elaphus): indication for a weak circadian clock in ungulates. - PloS One 9(9): e106997.

[10] Georgii, B. (1980): Home range patterns of female red deer (Cervus elaphus L.) in the Alps. - Oecologia 47(2): 278-285.

[11] Georgii, B., Schröder, W. (1983): Home range and activity patterns of male red deer (Cervus elaphus L.) in the Alps. - Oecologia 58(2): 238-248.

[12] Green, M. J. B. (1986): The distribution, status and conservation of the Himalayan mask deer (Moschus chrysogaster). - Biological Conservation 35(4): 347-375.

[13] Howell, J. C. (1954): Populations and home ranges of small mammals on an overgrown field. - Journal of Mammalogy 35(2): 177-186.

[14] Huber, S., Bruns, U., Arnold, W. (2002): Sex determination of red deer using polymerase chain reaction of DNA from feces. - Wildlife Society Bulletin 30(1): 208-212.

[15] Inglis, J. M., Hood, R. E., Brown, B. A., DeYoung, C. A. (1979): Home range of whitetailed deer in Texas Coastal Prairie Brushland. - Journal of Mammalogy 60(2): 377-389.

[16] Irwin, L. L., Peek, J. M. (1983): Elk habitat use relative to forest succession in Idaho. The Journal of Wildlife Management 47(3): 664-672.

[17] Jeppesen, J. L. (1987): Impact of human disturbance on home range, movements and activity of red deer (Cervus elaphus) in a Danish environment. - Danish Review of Game Biology 13(2): 1-38.

[18] Jetz, W., Carbone, C., Fulford, J., Brown, J. H. (2004): The scaling of animal space use. Science 306(5694): 266-268.

[19] Jiang, G. S., Zhang, M. H., Ma, J. Z. (2007): Effects of human disturbance on movement, foraging and bed selection in red deer Cervus elaphus xanthopygus from the Wandashan Mountains, northeastern China. - Acta Theriologica 52(4): 435-446.

[20] Kalinowski, S. T., Taper, M. L., Marshall, T. C. (2007): Revising how the computer program CERVUS accommodates genotyping error increases success in paternity assignment. - Molecular Ecology 16(5): 1099-1106.

[21] Kamler, J. F., Jędrzejewska, B., Jędrzejewski, W. (2007): Factors affecting daily ranges of red deer Cervus elaphus in Białowieża Primeval Forest, Poland. - Acta Theriologica 52(2): 113-118.

[22] Kamler, J. F., Jędrzejewski, W., Jędrzejewska, B. (2008): Home ranges of red deer in a European old-growth forest. - American Midland Naturalist 159(1): 75-82.

[23] Kohn, M. H., York, E. C., Kamradt, D. A., Haught, G., Sauvajot, R. M., Wayne, R. K. (1999): Estimating population size by genotyping faeces. - Proceedings of the Royal Society B: Biological Sciences 266(1420): 657-663.

[24] Koubek, P., Hrabe, V. (1996): Home range dynamics in the red deer (Cervus elaphus) in a mountain forest in central Europe. - Folia Zoologica 45(3): 219-222. 
[25] Kropil, R., Smolko, P., Garaj, P. (2015): Home range and migration patterns of male red deer Cervus elaphus in Western Carpathians. - European Journal of Wildlife Research 61(1): 63-72.

[26] Li, T., Jiang, J. S., Wu, Z. G., Han, X. D., Wu, J. C., Yang, X. J. (2001): Survey on Amur tiger in Jilin Province. - Acta Theriologica Sinica 21(1): 1-6.

[27] Ohtaishi, N., Sheng, H. L. (1993): Deer of China: Biology and Management. - Elsevier Science Publishers B.V., Amsterdam.

[28] Park, S. D. E. (2001): Trypanotolerance in West African Cattle and the Population Genetic Effects of Selection. - University of Dublin, Dublin.

[29] Pérez-Espona, S., Pérez-Barbería, F. J., Mcleod, J. E., Jiggins, C. D., Gordon, I. J., Pemberton, J. M. (2008): Landscape features affect gene flow of Scottish Highland red deer (Cervus elaphus). - Molecular ecology 17(4): 981-996.

[30] Qi, J. Z., Shi, Q. H., Wang, G. M., Li, Z. L., Sun, Q., Hua, Y., Jiang, G. S. (2015): Spatial distribution drivers of Amur leopard density in northeast China. - Biological Conservation 191: 258-265.

[31] Reinecke, H., Leinen, L., Thißen, I., Meißner, M., Herzog, S., Schütz, S., Kiffner, C. (2014): Home range size estimates of red deer in Germany: environmental, individual and methodological correlates. - European Journal of Wildlife Research 60(2): 237-247.

[32] Smith, D. A., Ralls, K., Hurt, A., Adams, B., Parker, M., Maldonado, J. E. (2006): Assessing reliability of microsatellite genotypes from kit fox faecal samples using genetic and GIS analyses. - Molecular Ecology 15(2): 387-406.

[33] Taberlet, P., Griffin, S., Goossens, B., Questiau, S., Manceau, V., Escaravage, N., Waits, L. P., Bouvet, J. (1996): Reliable genotyping of samples with very low DNA quantities using PCR. - Nucleic Acids Research 24(16): 3189-3194.

[34] Taberlet, P., Camarra, J. J., Griffin, S., Uhrès, E., Hanotte, O., Waits, L. P., DuboisPaganon, C., Burke, T., Bouvet, J. (1997): Noninvasive genetic tracking of the endangered Pyrenean brown bear population. - Molecular Ecology 6(9): 869-876.

[35] Tian, X. M., Zhang, M. H. (2010): Population size and sex ratio of wapiti (Cervus elephus xanthopygus) as revealed by fecal DNA. - Acta Ecologica Sinica 30(22): 62496254.

[36] Tian, X. M., Zhang, M. H., Zhang, H., Yang, C. W., Jin, Z. M. (2010): Genetic diversity of wapiti population in eastern Wandashan Mountains of Heilongjiang Province, China based on microsatellite analysis. - Chinese Journal of Ecology 29(3): 543-548.

[37] Wang, S. (1998): China red data book of endangered animals. - Beijing: Science Press.

[38] Woolnough, A., Toit, J. D. (2001): Vertical zonation of browse quality in tree canopies exposed to a size-structured guild of African browsing ungulates. - Oecologia 129(4): 585-590.

[39] Xu, Q. X., Zhang, M. H., Lu, B. X. (2000): Study on the status of red deer population in Heilongjiang Province. - Journal of Economic Animal 4(1): 57-62.

[40] Zhang, C. Z., Zhang, M. H. (2011): Population status and dynamic trends of Amur tiger's prey in eastern Wandashan Mountains, Heilongjiang Province. - Acta Ecologica Sinica 31(21): 6481-6487.

[41] Zhou, S. C., Sun, H. Y., Yang, J., Huang, H. J. (2015): Study on population dynamic trends of Amur tiger's prey and impact factors in eastern Wandashan Mountains. Forestry Science \& Technology 40(3): 37-40. 